\title{
NMDA Receptor NR2 Subunit Dependence of the Slow Component of Magnesium Unblock
}

\author{
Richard J. Clarke ${ }^{1,2}$ and Jon W. Johnson ${ }^{1,2}$ \\ ${ }^{1}$ Department of Neuroscience and ${ }^{2}$ Center for Neuroscience, University of Pittsburgh, Pittsburgh, Pennsylvania 15260
}

\begin{abstract}
NMDA receptor activity is important for many physiological functions, including synapse formation and alterations in synaptic strength. NMDA receptors are composed most commonly of NR1 and NR2 subunits. There are four NR2 subunits (NR2A-NR2D). NR2 subunit expression varies across both brain regions and developmental stages. The identity of the NR2 subunit within a functional NMDA receptor helps to determine many pharmacological and biophysical receptor properties, including strength of block by external $\mathrm{Mg}^{2+}$ $\left(\mathrm{Mg}_{\mathrm{o}}^{2+}\right) \cdot \mathrm{Mg}_{\mathrm{o}}^{2+}$ block confers strong voltage dependence to NMDA receptor-mediated responses and is critically important for many of the functions that the NMDA receptor plays within the CNS. Here we describe the NR2 subunit dependence of the kinetics of $\mathrm{Mg}_{\mathrm{o}}^{2+}$ unblock after rapid depolarizations. We find that $\mathrm{Mg}_{\mathrm{o}}^{2+}$ unblocks from NR1/2A and NR1/2B receptors with a prominent slow component similar to that previously described in native hippocampal and cortical NMDA receptors. Strikingly, this slow component of $\mathrm{Mg}_{\mathrm{o}}^{2+}$ unblock is completely absent from NR1/2C and NR1/2D receptors. Thus currents from NR1/2C and NR1/2D receptors respond more rapidly to fast depolarizations than currents from NR1/2A and NR1/2B receptors. In addition, the slow component of $\mathrm{Mg}_{\mathrm{o}}^{2+}$ unblock from NR1/2B receptors is consistently slower than from NR1/2A receptors. This makes rapid depolarizations, such as action potential waveforms, more efficacious at stimulating $\mathrm{Mg}_{\mathrm{o}}^{2+}$ unblock from NR1/2A than from NR1/2B receptors. These NR2 subunit differences in the kinetics of $\mathrm{Mg}_{\mathrm{o}}^{2+}$ unblock are likely to help determine the contribution of each NMDA receptor subtype to current flow during synaptic activity.
\end{abstract}

\section{Introduction}

Postsynaptic NMDA receptor responses are characterized by strong voltage dependence, slow decay, and a large calcium $\left(\mathrm{Ca}^{2+}\right)$ conductance. In part because of these unique characteristics, NMDA receptors are involved critically in synapse formation and modification during development (Bear et al., 1990; Cline et al., 1990; Iwasato et al., 2000; Ramoa et al., 2001; Erisir and Harris, 2003) as well as changes in synaptic strength in adulthood (Bliss and Collingridge, 1993; Heynen et al., 2000; Lisman and McIntyre, 2001). NMDA receptor dysfunction also has been implicated in many diseases such as epilepsy, schizophrenia, and several neurodegenerative disorders (Meldrum, 1992; Chapman, 2000; Cull-Candy et al., 2001; Tsai and Coyle, 2002; Zeron et al., 2002; Moghaddam, 2003).

Functional NMDA receptors are obligate heterotetramers, composed primarily of NR1 and NR2 subunits. The NR1 subunit has one gene product but many splice variants, which are expressed ubiquitously (Laurie et al., 1995). In contrast, expression of the four NR2 subunit gene products (NR2A-NR2D) shows tight temporal and spatial regulation. For example, NR2B and NR2D subunits are expressed prenatally, whereas NR2A and NR2C subunit expression rises sharply after birth (Monyer et al., 1994; Wenzel et al., 1996). Differential NR2 subunit expression

Received Feb. 8, 2006; revised April 18, 2006; accepted April 18, 2006

This work was supported by National Institute of Mental Health Grants MH045817 (J.W.J.) and T32 MH18273 (R.C.). We thank Xixi Chen and Dan Johnston for the somatic AP waveform.

Correspondence should be addressed to Jon W. Johnson, Department of Neuroscience, 446 Crawford Hall, University of Pittsburgh, Pittsburgh, PA 15260. E-mail: johnson@bns.pitt.edu.

DOI:10.1523/JNEUROSCI.0577-06.2006

Copyright $\odot 2006$ Society for Neuroscience $\quad$ 0270-6474/06/265825-10\$15.00/0 also occurs across brain regions. In adulthood NR2A and NR2B subunits predominate within the cortex, whereas NR2C and NR2D subunits are found within midbrain and hindbrain structures (Monyer et al., 1994; Wenzel et al., 1996). NR2 subunits even show differential expression within individual neurons; NR2A subunits cluster around synapses, whereas NR2B subunits often occupy extrasynaptic sites (Tovar and Westbrook, 1999). NR2 subunit expression is controlled tightly because NR2 subunits help to determine many pharmacological and biophysical receptor properties, including external $\mathrm{Mg}_{\mathrm{o}}^{2+}\left(\mathrm{Mg}_{\mathrm{o}}^{2+}\right)$ affinity (Dingledine et al., 1999).

Because of voltage-dependent channel block by $\mathrm{Mg}_{\mathrm{o}}^{2+}$ (Mayer et al., 1984; Nowak et al., 1984; Ascher and Nowak, 1988), NMDA receptor-mediated currents are prominent only during periods of coincident glutamate release and postsynaptic depolarization. Recent reports have shown that, after rapid membrane depolarization, $\mathrm{Mg}_{\mathrm{o}}^{2+}$ unblock from native NMDA receptors contains fast $(\tau<1 \mathrm{~ms})$ and slow $(\tau=3-20 \mathrm{~ms})$ components (Spruston et al., 1995; Vargas-Caballero and Robinson, 2003; Kampa et al., 2004). These findings are surprising because the kinetics of $\mathrm{Mg}_{\mathrm{o}}^{2+}$ unblock at the single-channel level (Nowak et al., 1984; Ascher and Nowak, 1988) predict only rapid unblock. Instead, the slow component or components account for as much as $50 \%$ of the total current relaxation, which reduces NMDA receptor currents during the upstroke of action potentials (APs) (Vargas-Caballero and Robinson, 2003) and shortens the time window for spike timing-dependent plasticity (STDP) (Kampa et al., 2004).

Previous studies describing slow $\mathrm{Mg}_{\mathrm{o}}^{2+}$ unblock were performed on native NMDA receptors of an undefined subunit composition. Here, we set out to determine whether the proper- 
ties of $\mathrm{Mg}_{\mathrm{o}}^{2+}$ unblock are NR2 subunit-dependent. We find that the relative speed of $\mathrm{Mg}_{\mathrm{o}}^{2+}$ unblock from NMDA receptor subtypes is represented by the following: NR1/2C, NR1/2D $\gg N R 1 /$ $2 \mathrm{~A}>\mathrm{NR} 1 / 2 \mathrm{~B}$. These NR2 subunit differences in $\mathrm{Mg}_{\mathrm{o}}^{2+}$ unblock render brief depolarizations, such as APs, more effective at stimulating $\mathrm{Mg}_{\mathrm{o}}^{2+}$ unblock from NR1/2A than from NR1/2B receptors.

\section{Materials and Methods}

Cell culture and transfection. Human embryonic kidney (HEK) 293T cells were maintained as previously described (Qian et al., 2005). HEK 293T cells were plated onto untreated glass coverslips or onto glass coverslips pretreated with poly-D-lysine $(0.1 \mathrm{mg} / \mathrm{ml})$ and rat-tail collagen $(0.1 \mathrm{mg} /$ $\mathrm{ml}$; BD Biosciences, San Jose, CA) in $35 \mathrm{~mm}$ culture dishes at $1-2 \times 10^{5}$ cells per dish. At 18-24 h after plating the cells were transiently transfected with cDNAs encoding the NR1-1a and one of the four NR2 subunits (NR2A-NR2D), using a modified $\mathrm{Ca}^{2+}$ precipitation procedure (Qian et al., 2005). The cDNA for enhanced green fluorescent protein (eGFP) was cotransfected as a marker of successful transfection. A total of $0.7 \mu \mathrm{g}$ of eGFP, $1.3 \mu \mathrm{g}$ of NR1-1a, and $2-8 \mu \mathrm{g}$ of NR2A-NR2D cDNA were used per dish. After incubation of the cells with the transfection solution for $6-8 \mathrm{~h}$, the precipitates were washed off with fresh culture medium that contained 200-1000 $\mu \mathrm{M} \mathrm{APV}$ and $2 \mathrm{mM} \mathrm{Mg}^{2+}$. Experiments were performed $20-72 \mathrm{~h}$ after transfection.

Solutions. Solutions were prepared daily from frozen stocks. Currents were activated by the indicated concentration of NMDA or glutamate either in the absence of $\mathrm{Mg}_{\mathrm{o}}^{2+}$ or with $1 \mathrm{~mm}$ added $\mathrm{Mg}_{\mathrm{o}}^{2+}$. Glycine $(10 \mu \mathrm{M})$ was added to all solutions. We did not adjust for changes in osmolality that resulted from the addition of $\mathrm{Mg}_{\mathrm{o}}^{2+}$. The external solution contained the following (in mM): $140 \mathrm{NaCl}, 1 \mathrm{CaCl}_{2}, 2.8 \mathrm{KCl}$, and $10 \mathrm{HEPES}, \mathrm{pH}$ 7.2, adjusted with $\mathrm{NaOH}$ (osmolality, $290 \pm 10 \mathrm{mmol} / \mathrm{kg}$ ). The internal solution contained the following (in mM): $125 \mathrm{CsCl}, 10 \mathrm{EGTA}$, and 10 HEPES, pH 7.2, adjusted with CsOH (osmolality, $275 \pm 10 \mathrm{mmol} / \mathrm{kg}$ ). Sucrose was used as needed to adjust the osmolality of the external solution. The junction potential between the pipette and bath solution was 5 $\mathrm{mV}$, and all holding potentials were corrected for junction potentials. Ultrapure salts were used when available. All chemicals were from Sigma (St. Louis, MO).

Whole-cell recording. Whole-cell recordings from transfected HEK 293T cells were performed as described previously (Qian et al., 2005). Briefly, pipettes were pulled from borosilicate standard walled glass with filaments $(1.5 \mathrm{~mm}$ outer diameter; $0.86 \mathrm{~mm}$ inner diameter; Warner Instruments, Hamden, CT) and fire-polished to a resistance of 2-5 M $\Omega$. Solutions were delivered with the use of an in-house fabricated fast perfusion system (Qian et al., 2002) connected to an eight chamber gravityfed solution reservoir (AutoMate Scientific, San Francisco, CA). Solution exchanges were $90 \%$ complete within $20 \mathrm{~ms}$ for standard whole-cell experiments or $90 \%$ complete within $1 \mathrm{~ms}$ for the lifted cell experiments. Solution exchange measurements were made by recording whole-cell current from a transfected HEK 293T cell while moving between two barrels. Both barrels contained the same concentration of NMDA and glycine, but one barrel contained normal extracellular solution and the second barrel contained an extracellular solution with the impermeant ion $\mathrm{N}$-methyl-D-glucamine (NMDG) in place of $\mathrm{NaCl}$. The time course of current decrease after movement into the NMDG extracellular solution was used to estimate solution exchange times.

In some experiments the lifted cell technique (Vicini et al., 1998) was used to permit faster solution exchange times. For these experiments the HEK 293T cells were plated onto untreated glass coverslips. Once wholecell access was obtained, negative pressure was reapplied, and the cell was lifted slowly into the solution flow. Small negative pressure was maintained throughout the experiment to prolong the duration of the experiment. The morphology of the cell was monitored continuously; if gross morphological changes occurred, the experiment was terminated.

All currents were recorded with an Axopatch 200 amplifier (Molecular Devices, Union City, CA) in voltage-clamp mode. The built-in series resistance correction and prediction circuitry were set to at least $80 \%$ in all experiments. Signals were low-pass filtered at 2.5 or $5 \mathrm{kHz}$ (eight-pole
Bessel; Warner Instruments) and sampled at $10-50 \mathrm{kHz}$. Where indicated, signals were refiltered at $1 \mathrm{kHz}$ for display. All experiments were performed at room temperature.

Data analysis and curve fitting. NMDA receptor-mediated current responses to depolarizing voltage jumps were corrected for leak and capacitive currents by subtracting the current response to an identical voltage jump in the absence of NMDA or glutamate, using pClamp 9.2 (Molecular Devices). When multiple sweeps of the same amplitude voltage jump were obtained, responses in the absence of NMDA or glutamate were averaged first and then subtracted from the agonist-induced ensemble average. Leak- and capacitive-subtracted currents $\left(I_{\mathrm{NMDA}}\right)$ then were fit with multi-exponential equations of the following form:

$$
I_{\mathrm{NMDA}}=C+\sum_{i=1}^{n} A_{i}\left(1-\exp \left(-t / \tau_{i}\right)\right),
$$

where $C$ is the current level before the voltage jump and $A_{i}$ is the amplitude of the exponential component, with time constant $\tau_{\mathrm{i}} ; n$ was adjusted between 1 and 3 as necessary to obtain quality fits. $C, A$, and $\tau_{\mathrm{i}}$ were allowed to vary during fitting. The amplitudes were expressed as a percentage by dividing each $A_{i}$ by the sum of the $A_{i}$ values of all of the exponential components. In experiments in which voltage jumps to 35 $\mathrm{mV}$ were applied shortly after agonist application (see Fig. 7), currents were normalized before fitting to remove the effects of desensitization. Currents were normalized to the average of two responses (prevoltage jump and postvoltage jump) to agonist application while the cell was held at $35 \mathrm{mV}$ to account for current rundown. All curve fitting was performed with Clampfit 9.2 (Molecular Devices) or Origin 7.0 (OriginLab, Northampton, MA). Data are expressed as the means \pm SEM, and statistical analysis was performed by using Student's $t$ tests unless otherwise noted.

\section{Results}

\section{NR2 subunit identity controls $\mathrm{Mg}_{\mathrm{o}}^{2+}$ unblocking kinetics}

The rapid unblocking kinetics of $\mathrm{Mg}_{\mathrm{o}}^{2+}$ at the single-channel level (Nowak et al., 1984; Ascher and Nowak, 1988) predict that, during whole-cell recordings, membrane depolarization would induce rapid $\mathrm{Mg}_{\mathrm{o}}^{2+}$ unblock. However, recent data (Spruston et al., 1995; Vargas-Caballero and Robinson, 2003; Kampa et al., 2004) have shown that, after rapid membrane depolarization, $\mathrm{Mg}_{\mathrm{o}}^{2+}$ unblock from native NMDA receptors of an undefined subunit composition actually contains both fast $(\tau<1 \mathrm{~ms})$ and slow $(\tau=$ 3-20 ms) components. Because the identity of the NR2 subunit within a functional NMDA receptor influences many channel properties (Dingledine et al., 1999), we first investigated whether the kinetics of $\mathrm{Mg}_{\mathrm{o}}^{2+}$ unblock are also NR2 subunit-dependent. To obtain a homogenous population of NMDA receptors with a defined subunit composition, we cotransfected HEK 293T cells with the cDNA for the NR1-1a subunit and the cDNA for one of the four NR2 subunits (NR2A-NR2D). HEK 293T cells are well suited for these experiments because the cells are electrotonically compact, which eliminates any slow changes in current because of poor space clamp, as may be seen with neuronal cells (VargasCaballero and Robinson, 2003).

We first applied depolarizing voltage steps from $-65 \mathrm{mV}$ during long applications (15 s) of NMDA in the absence and presence of $\mathrm{Mg}_{\mathrm{o}}^{2+}$ (Fig. 1 A,B). Long applications of NMDA allowed whole-cell currents to reach a steady-state level despite varying degrees of desensitization among NMDA subtypes (Dingledine et al., 1999). In the presence of physiological concentrations of $\mathrm{Mg}^{2+}(1 \mathrm{mM})$, block of the NR1/2A and NR1/2B receptormediated currents was nearly complete at $-65 \mathrm{mV}$ (94.7 \pm 0.6 and $96.1 \pm 1.3 \%$, respectively), whereas NR2C and NR2D receptors showed substantially less block $(78.6 \pm 0.4$ and $77.9 \pm 2.0 \%$, respectively). This is consistent with previous reports (Monyer et 
A

NMDA
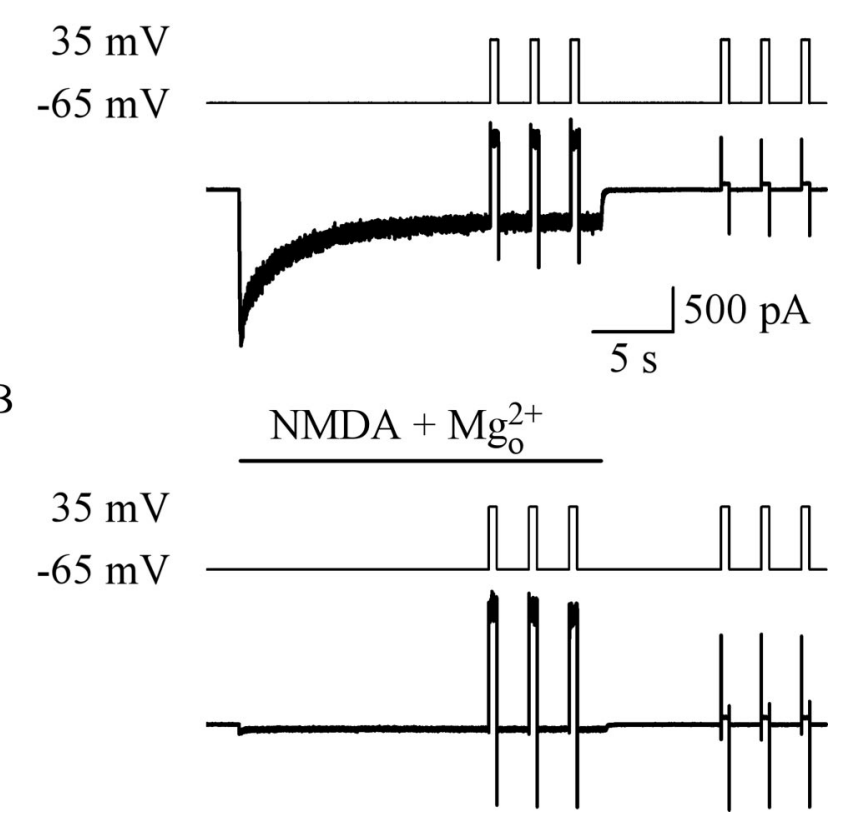

Figure 1. Protocol used to investigate the kinetics of $\mathrm{Mg}_{0}^{2+}$ unblock from recombinant NMDA receptors during steady-state response. NMDA $(30 \mu \mathrm{M})$ and glycine $(10 \mu \mathrm{M})$ (termed NMDA) was applied (top trace) in the absence $(\boldsymbol{A})$ and presence $(\boldsymbol{B})$ of $1 \mathrm{~mm}$ added $\mathrm{Mg}_{0}^{2+}$ during standard whole-cell recordings from an HEK 293T cell expressing NR1/2B receptors. Once the current (bottom trace) had reached a stationary level, three depolarizing voltage jumps (here, from -65 to $35 \mathrm{mV}$; middle trace) were applied. After termination of the NMDA application, another identical set of depolarizing voltage jumps was applied to allow for off-line leak and capacitive subtraction. All three sweeps in the absence and presence of NMDA were averaged before subtraction. Current traces were refiltered at $1 \mathrm{kHz}$ for display.

al., 1994; Kuner and Schoepfer, 1996; Qian et al., 2005) showing that $\mathrm{NR} 1 / 2 \mathrm{C}$ and $\mathrm{NR} 1 / 2 \mathrm{D}$ receptors have a lower affinity for $\mathrm{Mg}_{\mathrm{o}}^{2+}$ than do NR1/2A and NR1/2B receptors.

A depolarizing voltage jump to $35 \mathrm{mV}$ relieves the voltagedependent block by $\mathrm{Mg}_{\mathrm{o}}^{2+}$ from all receptor subtypes and allows outward current flow. However, in response to a depolarizing voltage step, outward currents in the presence of $1 \mathrm{mM} \mathrm{Mg}^{2+}$ from both NR1/A and NR1/2B receptors develop with both fast and slow components (Fig. $2 A_{2}, B_{2}$ ). The observed slow component is predominantly attributable to $\mathrm{Mg}_{\mathrm{o}}^{2+}$ unblock, because the same voltage jump performed in the absence of $\mathrm{Mg}_{\mathrm{o}}^{2+}$ results in a more rapid relaxation of outward current (Fig. $2 A_{1}, B_{1}$ ). Strikingly, after an identical depolarizing voltage jump, $\mathrm{Mg}_{\mathrm{o}}^{2+}$ unblocks from NR1/2C and NR1/2D receptors very rapidly, with no obvious slow component (Fig. $2 C_{2}, D_{2}$ ). The kinetics of outward currents from NR1/2C and NR1/2D receptors after a depolarizing voltage jump are also rapid in the absence of $\mathrm{Mg}_{\mathrm{o}}^{2+}$ (Fig. $\left.2 C_{1}, D_{1}\right)$. Thus, unlike NR1/2A and NR1/2B receptors, under these experimental conditions there is no slow $\mathrm{Mg}_{\mathrm{o}}^{2+}$ unblock from NR1/2C or NR1/2D receptors.

To quantify the kinetics of $\mathrm{Mg}_{\mathrm{o}}^{2+}$ unblock, we fit currents in response to voltage jumps from -65 to $35 \mathrm{mV}$ with a single or double exponential equation (Fig. 2). In the absence of added $\mathrm{Mg}_{\mathrm{o}}^{2+}$ the current relaxation from all receptor subtypes was dominated by a single fast (sub-millisecond) component. However, we did observe a small slow component of outward current relaxation in the absence of added $\mathrm{Mg}_{\mathrm{o}}^{2+}$ from both NR1/2A and NR1/2B receptors (Fig. $2 A_{1}, B_{1}$ ). Slow relaxation of NMDAmediated current after depolarizing voltage jumps in the absence
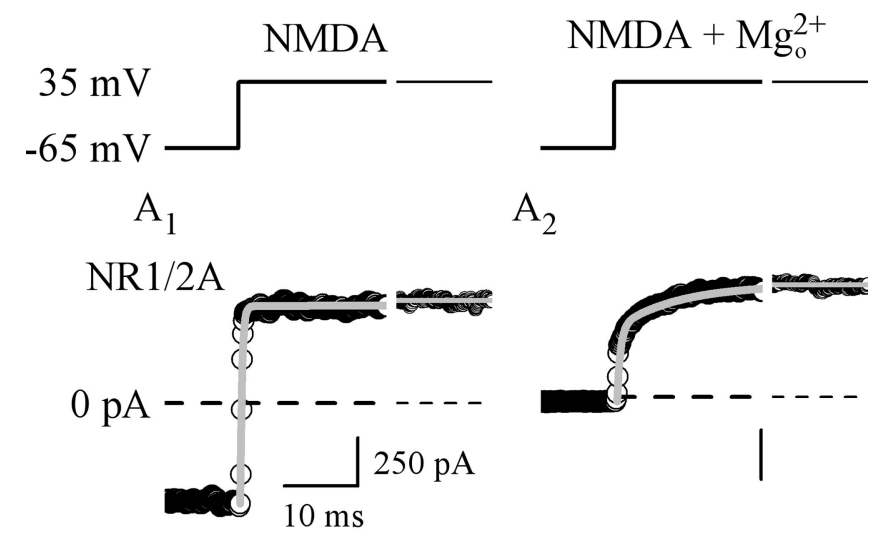

$\mathrm{B}_{1}$

$\mathrm{B}_{2}$
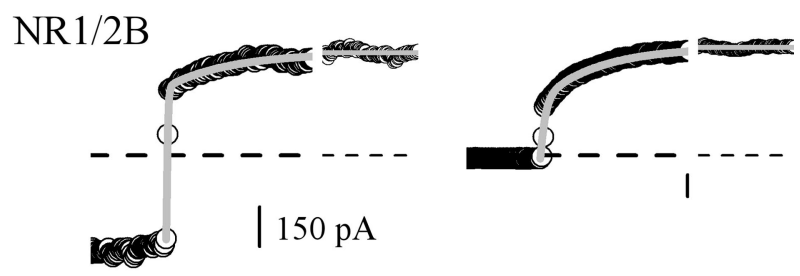

$\mathrm{C}_{1}$

$\mathrm{C}_{2}$
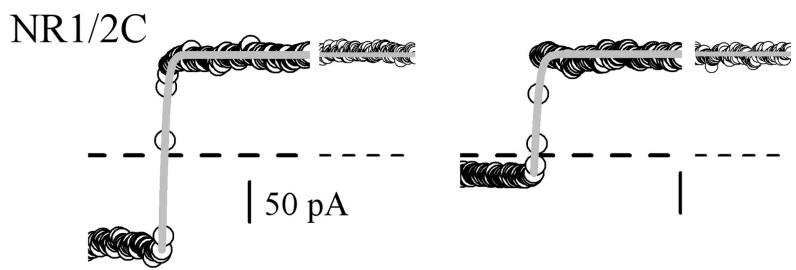

$\mathrm{D}_{1}$

$\mathrm{D}_{2}$
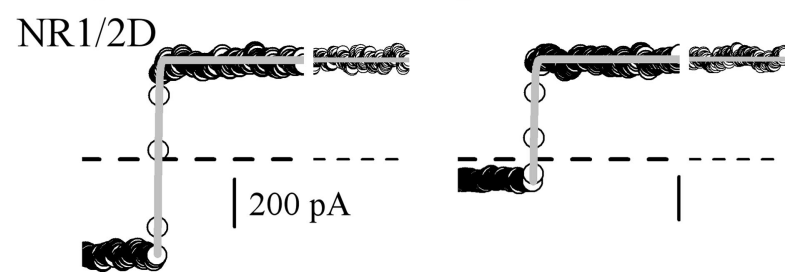

Figure 2. The kinetics of $\mathrm{Mg}_{0}^{2+}$ unblock are NR2 subunit dependent. Whole-cell currents are shown from NR1/2A $\left(\boldsymbol{A}_{1}, \boldsymbol{A}_{2}\right), \operatorname{NR} 1 / 2 \mathrm{~B}\left(\boldsymbol{B}_{1}, \boldsymbol{B}_{2}\right), \operatorname{NR} 1 / 2 C\left(\boldsymbol{C}_{1}, \boldsymbol{C}_{2}\right)$, and NR1/2D $\left(\boldsymbol{D}_{1}, \boldsymbol{D}_{2}\right)$ receptors during a $500 \mathrm{~ms}$ depolarizing voltage step from -65 to $35 \mathrm{mV}$. The voltage steps were applied either in the absence $\left(A_{1}-D_{1}\right)$ or in the presence of $1 \mathrm{~mm} \mathrm{Mg}_{0}^{2+}\left(A_{2}-D_{2}\right)$. A prominent slow relaxation of the outward current is present within records from NR $1 / 2 A$ and NR $1 / 2 B$ receptors when the depolarizing voltage jump is applied in the presence of $1 \mathrm{~mm} \mathrm{Mg}_{0}^{2+}$, indicating a slow component of $\mathrm{Mg}_{0}^{2+}$ unblock. In contrast, the outward current from NR1/2C and NR1/2D receptors in response to a depolarizing voltage jump relaxes with a single, fast component both in the absence and presence of $\mathrm{Mg}_{0}^{2+}$. NMDA indicates that the currents are recorded in the presence of $30 \mu \mathrm{M}$ NMDA and $10 \mu \mathrm{m}$ glycine. The timing of the voltage jump is indicated by the traces above $A_{1}$ and $A_{2}$, and the 0 current level is indicated by a horizontal dashed line. Double $\left(A_{1}-B_{2}\right)$ or single $\left(\boldsymbol{C}_{\boldsymbol{1}}-\boldsymbol{D}_{2}\right)$ exponential fits are overlaid (gray lines). Note the different calibration in $\boldsymbol{B}_{\boldsymbol{1}}$ and $\boldsymbol{B}_{2}$ because of the potentiation of NR1/2B receptors by $\mathrm{Mg}_{0}^{2+}$ (Paoletti et al., 1995).

of $\mathrm{Mg}_{\mathrm{o}}^{2+}$ has been reported previously (Benveniste and Mayer, 1995; Spruston et al., 1995) (but see Vargas-Caballero and Robinson, 2003; Kampa et al., 2004). In our hands the kinetics of current relaxation after a depolarizing voltage jump to $35 \mathrm{mV}$ with zero-added $\mathrm{Mg}_{\mathrm{o}}^{2+}$ are dominated by a fast (sub-millisecond) 


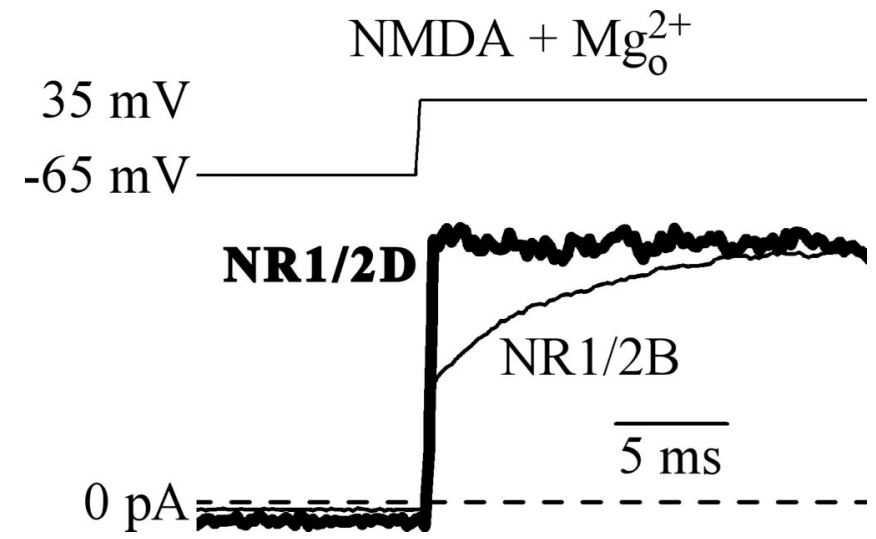

Figure 3. $\mathrm{Mg}_{0}^{2+}$ unblocks rapidly from NR2D receptors even at high $\left[\mathrm{Mg}_{0}^{2+}\right]$. Shown are superimposed whole-cell currents during a voltage jump from -65 to $35 \mathrm{mV}$ from NR1/2B receptors in the presence of $30 \mu \mathrm{M} N \mathrm{NDA}, 10 \mu \mathrm{m}$ glycine, and $1 \mathrm{~mm} \mathrm{Mg}_{0}^{2+}$ (thin trace) or $\mathrm{NR} 1 / 2 \mathrm{D}$ receptors in the presence of $30 \mu \mathrm{m} \mathrm{NMDA}, 10 \mu \mathrm{m}$ glycine, and $5 \mathrm{~mm} \mathrm{Mg}_{0}^{2+}$ (thick trace). Currents are normalized to the steady-state outward current at $35 \mathrm{mV}$. Note the comparable level of inward current mediated by each of the two receptor isoforms. Voltage change is indicated by the top trace; the 0 current level is indicated by a dashed horizontal line.

component, with the slow component having a small percentage of amplitude $(<15 \%)$ that in every case is significantly $(p<0.01)$ less than the amplitude of the slow component in the presence of $\mathrm{Mg}_{\mathrm{o}}^{2+}$ (supplemental Table 1, available at www.jneurosci.org as supplemental material).

In the presence of $\mathrm{Mg}_{\mathrm{o}}^{2+}$ the $\mathrm{NR} 1 / 2 \mathrm{~A}$ and $\mathrm{NR} 1 / 2 \mathrm{~B}$ receptor currents were well fit by a double exponential equation, whereas a single exponential equation provided excellent fits of currents from NR1/2C and NR1/2D receptors both in the presence and absence of $\mathrm{Mg}_{\mathrm{o}}^{2+}$ (Fig. 2). The tau of the fast component $\left(\tau_{1}\right)$ did not differ significantly among any of the receptor subtypes or depend on the presence of $\mathrm{Mg}^{2+}$, with a value of $\sim 0.5 \mathrm{~ms}$ under all conditions (supplemental Table 1, available at www.jneurosci. org as supplemental material). The tau of the slow component $\left(\tau_{2}\right)$ of $\mathrm{Mg}_{\mathrm{o}}^{2+}$ unblock from NR1/2A and NR1/2B receptors was significantly $(p<0.0001)$ slower than $\tau_{1}$, with values of $4.80 \pm$ $0.39 \mathrm{~ms}$ for NR1/2A $(n=6)$ and $9.15 \pm 0.83 \mathrm{~ms}$ for $\mathrm{NR} 1 / 2 \mathrm{~B}$ receptors $(n=8)$. In addition, $\tau_{2}$ was significantly $(p<0.005)$ slower from $\mathrm{NR} 1 / 2 \mathrm{~B}$ than from $\mathrm{NR} 1 / 2 \mathrm{~A}$ receptors (see below). In both NR1/2A and NR1/2B receptors the slow component accounted for $\sim 40 \%$ of the total current.

It is possible that we missed a small slow component of $\mathrm{Mg}_{\mathrm{o}}^{2+}$ unblock from NR1/2C and NR1/2D receptors because they are blocked less effectively by $1 \mathrm{mM} \mathrm{Mg}_{\mathrm{o}}^{2+}$ than are NR1/2A and NR1/2B receptors (Monyer et al., 1994; Kuner and Schoepfer, 1996; Qian et al., 2005). To test this possibility, we raised $\mathrm{Mg}_{\mathrm{o}}^{2+}$ to $5 \mathrm{~mm}$, a concentration at which the inhibition of NR1/2D receptor responses is comparable to inhibition of NR1/2B receptor responses by $1 \mathrm{mM} \mathrm{Mg}^{2+}$. Even under these conditions there was no hint of a slow component of $\mathrm{Mg}_{\mathrm{o}}^{2+}$ unblock from NR1/2D receptors (Fig. 3). The kinetics of $\mathrm{Mg}_{\mathrm{o}}^{2+}$ unblock from NR1/2D receptors were similar in the presence of 1 and $5 \mathrm{mM} \mathrm{Mg}^{2+}$, with time constants of $0.25 \pm 0.01$ and $0.30 \pm 0.07 \mathrm{~ms}$, respectively. The kinetics of $\mathrm{Mg}_{\mathrm{o}}^{2+}$ unblock from NR1/2A and NR1/2B receptors in the presence of $5 \mathrm{~mm}$ also were similar to those observed in the presence of $1 \mathrm{mM} \mathrm{Mg}_{\mathrm{o}}^{2+}$ (supplemental Table 1, available at www.jneurosci.org as supplemental material). Thus the kinetics of $\mathrm{Mg}_{\mathrm{o}}^{2+}$ unblock are determined by the identity of the NR2 subunit, with slow $\mathrm{Mg}_{\mathrm{o}}^{2+}$ unblock occurring only from NMDA receptors that contain either the NR2A or NR2B subunit.
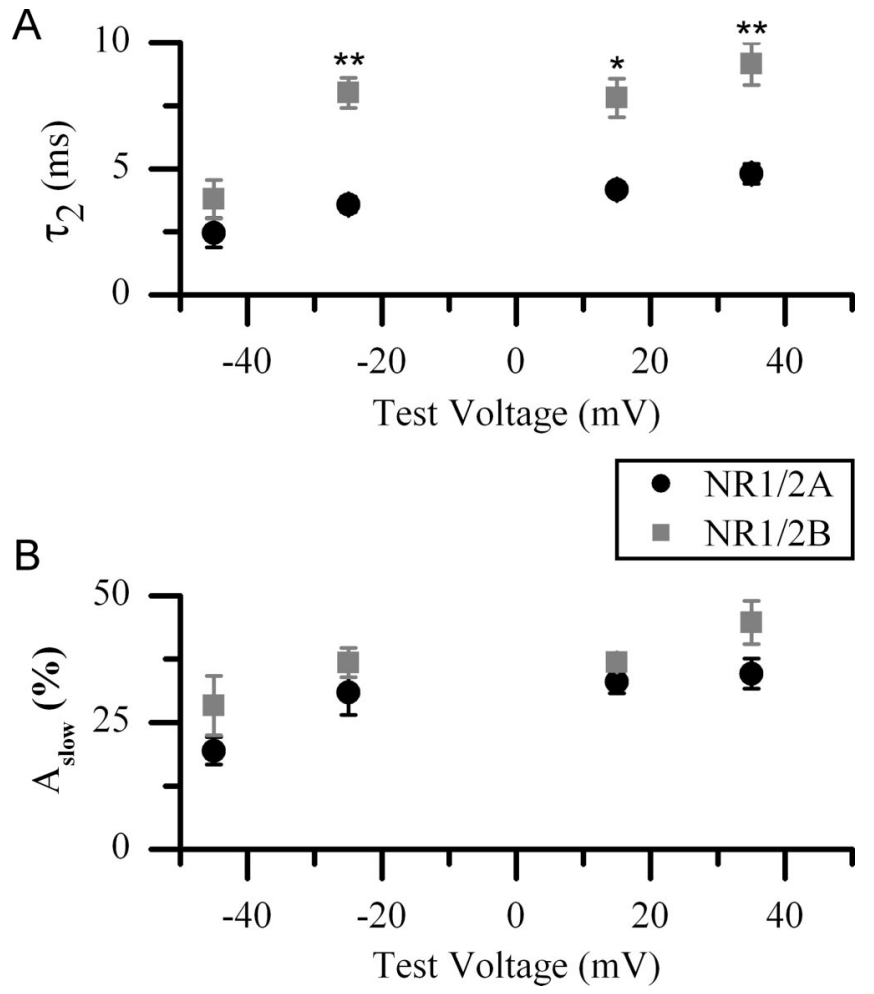

Figure 4. Quantification of the subunit and voltage dependence of $\mathrm{Mg}_{0}^{2+}$ unblocking kinetics. Shown are results from double-exponential fits to NR1/2A (black circles) and NR1/2B (gray squares) receptor currents in response to a depolarizing voltage jump from rest $(-65 \mathrm{mV})$ to the indicated test voltages in the presence of $30 \mu \mathrm{m} \mathrm{NMDA}, 10 \mu \mathrm{m}$ glycine, and $1 \mathrm{~mm} \mathrm{Mg}_{0}^{2+} \cdot \boldsymbol{A}$, Pooled results of $\tau_{2}$. $\tau_{2}$ from fits to NR1/2B receptor currents was significantly slower than $\tau_{2}$ from fits to NR1/2A receptor currents at all test voltages except $-45 \mathrm{mV}$. $\tau_{2}$ of both NR1/2A and $\mathrm{NR} 1 / 2 \mathrm{~B}$ receptors also showed weak voltage dependence, becoming significantly slower as the amplitude of the depolarizing voltage jump became larger. $\boldsymbol{B}$, Pooled results of $A_{\text {slow: }} \cdot A_{\text {slow }}$ did not differ significantly between NR1/2A and NR1/2B receptors and did not show any significant voltage dependence. Error bars indicate the means \pm SEM. ${ }^{*} p<0.01 ;{ }^{* *} p<0.005$.

\section{Voltage dependence of slow $\mathrm{Mg}_{\mathrm{o}}^{2+}$ unblock}

To characterize further the slow $\mathrm{Mg}_{\mathrm{o}}^{2+}$ unblock from NR1/2A and NR1/2B receptors, we applied depolarizing voltage jumps from rest to test voltages from -45 to $35 \mathrm{mV}$, using a protocol similar to that shown in Figure 1. The resulting currents were fit with single or double exponential equations. In the presence of $1 \mathrm{~mm}$ $\mathrm{Mg}_{\mathrm{o}}^{2+}$ a double exponential equation was required for adequate fits of currents in response to voltage jumps to each of the tested voltages, indicating that slow $\mathrm{Mg}_{\mathrm{o}}^{2+}$ unblock occurs throughout the physiological range of membrane voltages.

For both NR1/2B and NR1/2A receptors $\tau_{1}$ did not depend on the amplitude of the depolarization ( $p>0.05$; ANOVA), which enabled us to average the results across all test voltages. The averaged values for $\tau_{1}$ did not depend significantly on NR2 subunit identity or the presence of $\mathrm{Mg}_{\mathrm{o}}^{2+}$, with values of $0.40 \pm 0.11 \mathrm{~ms}$ $(n=16)$ and $0.31 \pm 0.02 \mathrm{~ms}(n=19)$ for NR1/2A receptors and $0.52 \pm 0.23 \mathrm{~ms}(n=19)$ and $0.38 \pm 0.13 \mathrm{~ms}(n=15)$ for $\mathrm{NR} 1 / 2 \mathrm{~B}$ receptors in the presence and absence of $\mathrm{Mg}_{\mathrm{o}}^{2+}$, respectively. In contrast, $\tau_{2}$ from NR1/2B receptors was significantly slower than $\tau_{2}$ from NR1/2A receptors at most test voltages (Fig. $4 A$ ). Only in response to the smallest amplitude voltage jump ( -65 to -45 $\mathrm{mV}$ ) was $\tau_{2}$ not significantly different between NR1/2A and NR1/2B receptors. $\tau_{2}$ from both NR1/2A and NR1/2B receptors did show weak voltage dependence ( $p<0.05$; ANOVA), becoming slower as the amplitude of the depolarizing step increased (Fig. 4). The amplitudes of the slow component $\left(A_{\text {slow }}\right)$ of $\mathrm{Mg}_{\mathrm{o}}^{2+}$ 


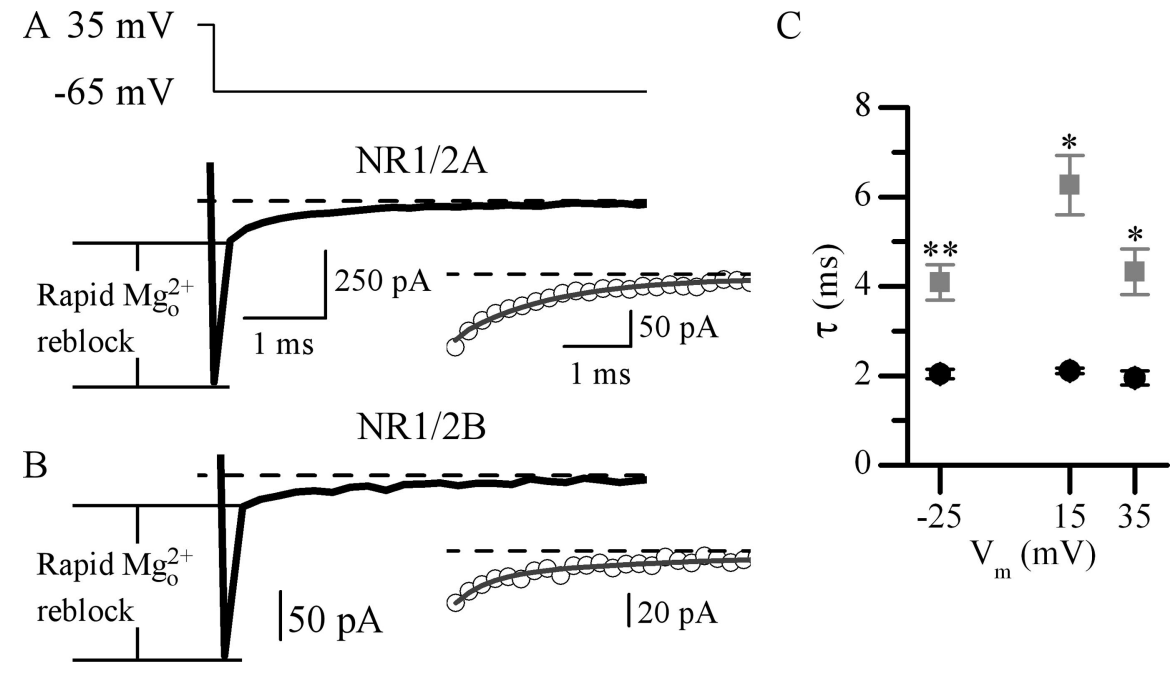

Figure 5. Slow reblock of $\mathrm{Mg}_{0}^{2+}$. Shown are example traces from NR1/2A $(A)$ and NR1/2B $(B)$ receptors that follow a voltage return to $-65 \mathrm{mV}$ after a $500 \mathrm{~ms}$ depolarization to $35 \mathrm{mV}$ in the presence of $30 \mu \mathrm{m} \mathrm{NMDA}, 10 \mu \mathrm{m}$ glycine, and $1 \mathrm{~mm} \mathrm{Mg}_{0}^{2+}$. The majority of $\mathrm{Mg}_{0}^{2+}$ reblock occurs in $<1 \mathrm{~ms}$ (indicated by rapid $\mathrm{Mg}_{0}^{2+}$ reblock). However, a slow phase of $\mathrm{Mg}_{0}^{2+}$ reblockis present, which delays the return to baseline current (indicated by dashed black line). Insets, Single exponential fits of the slow phase of $\mathrm{Mg}_{0}^{2+}$ reblock are overlaid as gray lines. C, Pooled results from fits to the slow phase of $\mathrm{Mg}_{0}^{2+}$ reblock. The time constant $(\tau)$ of slow $\mathrm{Mg}_{0}^{2+}$ reblock of NR1/2B receptors (gray squares) is significantly slower than the $\tau$ of slow $\mathrm{Mg}_{0}^{2+}$ reblock of NR1/2A receptors (black circles) after repolarization to $-65 \mathrm{mV}$ from $-25,15$, or $35 \mathrm{mV}$. Error bars indicate the means \pm SEM. ${ }^{*} p<0.05$; ${ }^{* *} p<0.01$.

unblock from NR1/2A and NR1/2B receptors were not significantly different (Fig. $4 B$ ), carrying $\sim 40 \%$ of the total depolarization-induced current relaxation at all test voltages. $A_{\text {slow }}$ did not display any significant voltage dependence $(p>$ 0.05 ; ANOVA) in either NR1/2A or NR1/2B receptors, although there was a trend for $A_{\text {slow }}$ to increase as the amplitude of the voltage jump increased.

If the slow component of $\mathrm{Mg}_{\mathrm{o}}^{2+}$ unblock resulted from slow unbinding of $\mathrm{Mg}_{\mathrm{o}}^{2+}$ from open NMDA receptor channels, $\tau_{2}$ should be strongly voltage-dependent and become faster with depolarization. Instead, we found that slow $\mathrm{Mg}_{\mathrm{o}}^{2+}$ unblock is only weakly voltage-dependent and becomes slower with depolarization (Fig. 4A), in agreement with previous data from native NMDA receptors (Vargas-Caballero and Robinson, 2003). Thus it is likely that the kinetics of slow $\mathrm{Mg}_{\mathrm{o}}^{2+}$ unblock arise from the slow exit of NMDA receptor channels from one or more closed block state(s) (see Discussion).

In the presence $\mathrm{Mg}_{\mathrm{o}}^{2+}$, returning the voltage to $-65 \mathrm{mV}$ caused rapid reblock of the channel (Fig. $5 A, B$ ). However, after depolarizations to $-25,15$, and $35 \mathrm{mV}$ a slow phase of $\mathrm{Mg}_{\mathrm{o}}^{2+}$ block was also present (Fig. $5 A, B$ ). In cells with large enough responses to allow adequate signal-to-noise ratios, we fit the slow portion of $\mathrm{Mg}_{\mathrm{o}}^{2+}$ reblock with a single exponential equation. The slow phase of $\mathrm{Mg}_{\mathrm{o}}^{2+}$ reblock of NR1/2B receptors was significantly slower than the slow phase of $\mathrm{Mg}^{2+}$ reblock of NR1/2A receptors after repolarization to $-65 \mathrm{mV}$ from $-25,15$, and 35 $\mathrm{mV}$ (Fig. $5 C$ ). In contrast, currents from NR1/2C and NR1/2D receptors showed very rapid reblock, which was well fit with a single exponential component with a $\tau$ of $<1 \mathrm{~ms}$ (data not shown). Together, these data indicate that the kinetics of both $\mathrm{Mg}_{\mathrm{o}}^{2+}$ unblock and reblock during rapid voltage changes are strongly dependent on the identity of the NR2 subunit.

\section{Dependence of $\mathrm{Mg}_{\mathrm{o}}^{2+}$ unblocking kinetics on agonist concentration}

Previous experiments investigating slow $\mathrm{Mg}_{\mathrm{o}}^{2+}$ unblock have disagreed as to the time course of slow unblock, varying from a single slow component with a $\tau$ of $14-23$ ms (Vargas-Caballero and Robinson, 2003) to two slow components, one with a $\tau$ of $\sim 4 \mathrm{~ms}$ and one with a $\tau>100 \mathrm{~ms}$ (Kampa et al., 2004). One prominent difference between these previous studies is the concentration of agonist used to activate NMDA receptors; Vargas-Caballero and Robinson (2003) used $25 \mu \mathrm{M}$ NMDA, whereas Kampa and colleagues (2004) used $1 \mathrm{~mm}$ glutamate. To determine whether the kinetics of $\mathrm{Mg}^{2+}$ unblock are dependent on the agonist concentration used to activate the receptors, we repeated the protocol described in Figure 1, using 1 $\mathrm{mm}$ glutamate or NMDA. Again, in response to a voltage step from -65 to 35 $\mathrm{mV}$ the currents from $\mathrm{NR} 1 / 2 \mathrm{~A}$ and NR1/2B receptors displayed a prominent slow component of $\mathrm{Mg}_{\mathrm{o}}^{2+}$ unblock (Fig. $6 A, B)$. In contrast, $\mathrm{Mg}_{\mathrm{o}}^{2+}$ unblock from $\mathrm{NR} 1 / 2 \mathrm{C}$ and NR1/2D receptors was dominated by a single fast component $(\tau<1$ ms) (supplemental Table 2, available at www.jneurosci.org as supplemental material), as observed previously in lower agonist conditions.

Unlike results using $30 \mu \mathrm{M}$ NMDA, $\mathrm{Mg}_{\mathrm{o}}^{2+}$ unblock from $\mathrm{NR} 1 / 2 \mathrm{~A}$ and NR1/2B receptors in these high agonist concentrations required a triple exponential equation for an adequate fit (Fig. 6C). The tau of the fast component $\left(\tau_{1}\right)$ of $\mathrm{Mg}_{\mathrm{o}}^{2+}$ unblock did not differ significantly between NR1/2A and NR1/2B receptors (Fig. $6 D$ ) or depend on the agonist concentration. In contrast, the tau of the dominant slow component $\left(\tau_{2}\right)$ of $\mathrm{Mg}_{\mathrm{o}}^{2+}$ unblock from NR1/2A receptors was significantly $(p<0.005)$ faster in $1 \mathrm{~mm}$ glutamate as compared with the corresponding $\tau_{2}$ of $\mathrm{Mg}_{\mathrm{o}}^{2+}$ unblock in the presence of $30 \mu \mathrm{M}$ NMDA. This was also true for the $\tau_{2}$ of $\mathrm{Mg}_{\mathrm{o}}^{2+}$ unblock from NR1/2B receptors. It seems reasonable to compare these two components because the third component observed only in high agonist conditions was the same in NR1/2A and NR1/2B receptors, had a time constant $\left(\tau_{3}\right)$ of several hundred milliseconds, and had a small $(<10 \%)$ amplitude (Fig. 6D,E). Despite showing faster kinetics at high agonist concentrations, the $\tau_{2}$ of $\mathrm{Mg}_{\mathrm{o}}^{2+}$ unblock was still NR2 subunitdependent; NR1/2B receptor $\tau_{2}$ was significantly slower and had a significantly larger amplitude than the corresponding $\tau_{2}$ from NR1/2A receptors (Fig. $6 D, E$ ).

For both NR1/2A and NR1/2B receptors the main difference between the kinetics of $\mathrm{Mg}_{\mathrm{o}}^{2+}$ unblock in $30 \mu \mathrm{M}$ NMDA versus 1 mM glutamate was an acceleration of the prominent slow component of unblock (termed $\tau_{2}$ in both agonist conditions). This could be an agonist-specific difference, but this is unlikely because similar results to those shown with $1 \mathrm{~mm}$ glutamate were obtained by using 1 mM NMDA (supplemental Table 2, available at www.jneurosci.org as supplemental material). Instead, this difference may result from an increase in channel open probability $\left(P_{\text {open }}\right)$ that results from increasing agonist concentration. The hypothesis that a larger $P_{\text {open }}$ leads to a faster $\tau_{2}$ of $\mathrm{Mg}_{\mathrm{o}}^{2+}$ unblock is consistent with our observation that $\tau_{2}$ is faster from NR1/2A than from NR1/2B receptors (Fig. 4); NR1/2A receptors have a higher $P_{\text {open }}$ than NR1/2B receptors (Chen et al., 1999; Erreger et al., 2005).

On the basis of this hypothesis, any manipulation that raises 
the $P_{\text {open }}$ of the receptor should accelerate the slow component of $\mathrm{Mg}_{\mathrm{o}}^{2+}$ unblock. To test this hypothesis, we repeated the protocol in Figure 1 with NR1/2B receptors at $\mathrm{pH}$ 8.2, which reduces proton inhibition (Giffard et al., 1990; Tang et al., 1990; Traynelis and Cull-Candy, 1990) and hence raises $P_{\text {open. }}$. Under these conditions $\tau_{2}$ was significantly $(p=0.02)$ accelerated from $9.15 \pm 0.93 \mathrm{~ms}$ at $\mathrm{pH} 7.2$ to $3.93 \pm$ $0.77 \mathrm{~ms}$ at $\mathrm{pH} 8.2$. $A_{\text {slow }}$ also was reduced from $44.7 \pm 4.8 \%$ at $\mathrm{pH} 7.2$ to $32.7 \pm$ $1.3 \%$ at $\mathrm{pH} 8.2$, although this difference did not reach statistical significance. These data support the hypothesis that the differences in $\mathrm{Mg}_{\mathrm{o}}^{2+}$ unblock from NR1/2A and NR1/2B receptors are attributable to differences in $P_{\text {open }}$.

\section{Effect of the timing of membrane depolarization on $\mathrm{Mg}_{\mathrm{o}}^{2+}$ unblocking kinetics}

The relative timing of synaptic NMDA receptor activation and postsynaptic depolarization plays a critical role in determining whether $\mathrm{Ca}^{2+}$ influx via NMDA receptors will lead to long-term changes in synaptic strength (Magee and Johnston, 1997; Markram et al., 1997; Bi and Poo, 1998). Previous work has shown that the kinetics of $\mathrm{Mg}_{\mathrm{o}}^{2+}$ unblock from native NMDA receptors also depend on the relative timing of receptor activation and postsynaptic depolarization; unblock is slower after prolonged receptor activation (Kampa et al., 2004). We next determined whether the kinetics of $\mathrm{Mg}_{\mathrm{o}}^{2+}$ unblock are NR2 subunitdependent when unblock is stimulated shortly after receptor activation.

For these experiments we used lifted HEK 293T cells, which allowed for rapid exchange of the external solution (90\% complete in $<1 \mathrm{~ms}$ ). To verify that glutamate application to lifted HEK 293T cells transfected with NR1/2A or NR1/2B receptors was rapid, we measured the rise time of NMDA currents. The $10-90 \%$ rise times of currents activated by $1 \mathrm{~mm}$ glutamate in the presence of $1 \mathrm{mM} \mathrm{Mg}^{2+}$ at a constant membrane potential of -65 $\mathrm{mV}$ was, for NR1/2A receptors, $4.87 \pm 0.61 \mathrm{~ms}(n=6)$ and, for $\mathrm{NR} 1 / 2 \mathrm{~B}$ receptors, $9.95 \pm 1.39 \mathrm{~ms}(n=5)$. These are similar to previously published values for the rise times of NR1/2A and $\mathrm{NR} 1 / 2 \mathrm{~B}$ receptor currents in the absence of $\mathrm{Mg}_{\mathrm{o}}^{2+}$ (Chen et al., 1999; Erreger et al., 2005).

In the presence of $1 \mathrm{mM} \mathrm{Mgo}^{2+}$ the rapid glutamate applications at $35 \mathrm{mV}$ resulted in large outward currents, whereas current responses to glutamate applications at $-65 \mathrm{mV}$ mainly were blocked in both NR1/2A and NR1/2B receptors (Fig. 7A,B). Voltage jumps from -65 to $35 \mathrm{mV}$ applied after a $\sim 15 \mathrm{~ms}$ delay that followed glutamate application resulted in outward currents that relaxed toward the current observed during glutamate application with the cell held at $35 \mathrm{mV}$. However, the current in response to the voltage jump did not immediately join the current during the glutamate application at $35 \mathrm{mV}$, indicating a slow component of $\mathrm{Mg}_{\mathrm{o}}^{2+}$ unblock (Fig. $7 \mathrm{~A}, B$ ). The voltage jump was time-locked to barrel movement signal, which resulted in some jitter between receptor activation and membrane depolarization
A

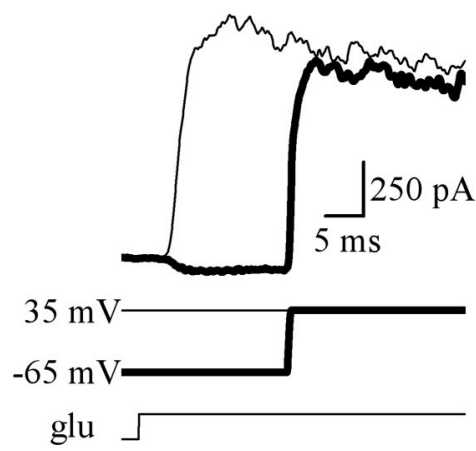

B

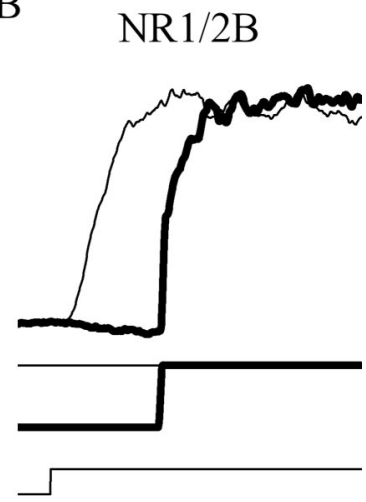

Figure 7. $\mathrm{Mg}_{0}^{2+}$ unblock near the time of onset of NMDA receptor activity. Shown are example traces during a rapid application of $1 \mathrm{~mm}$ glutamate in the presence of $1 \mathrm{~mm} \mathrm{Mg}_{0}^{2+}$ while the cell was held either at $35 \mathrm{mV}$ (thin trace) or during a voltage jump from -65 to $35 \mathrm{mV}$ (thick trace) from NR1/2A receptors $(\boldsymbol{A})$ and NR1/2B receptors $(\boldsymbol{B})$. The timing of the voltage jump and the barrel movement are indicated by the middle and bottom traces, respectively. Current traces were refiltered at $1 \mathrm{kHz}$ for display.

because of variability in the distance between the barrels and the lifted cell. However, the average timing between receptor activation and membrane depolarization was similar in NR1/2A (15.0 $\mathrm{ms}$ ) and NR1/2B (14.3 ms) receptors.

To quantify the kinetics of $\mathrm{Mg}_{\mathrm{o}}^{2+}$ unblock, we normalized the current in response to the voltage jump to the current evoked by glutamate application while the cell was held at $35 \mathrm{mV}$. The normalized currents in response to these voltage jumps that occurred shortly after receptor activation were well fit with a double expo- 


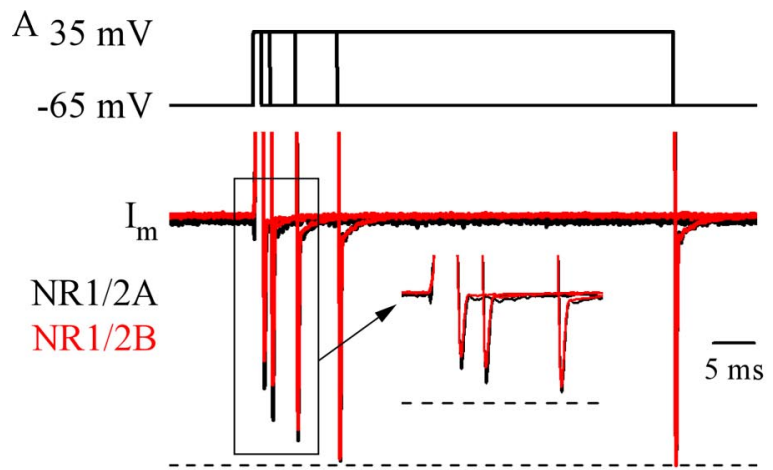

$\mathrm{C}$

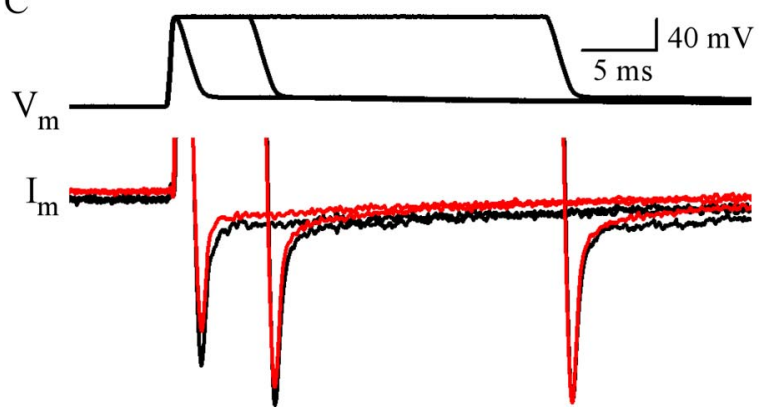

B

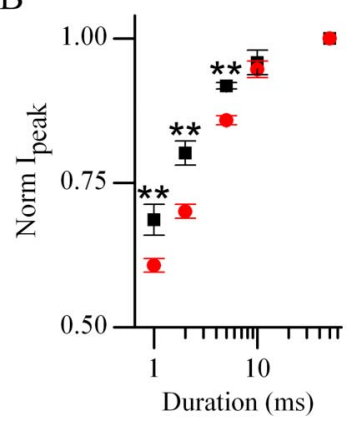

$\mathrm{D}$

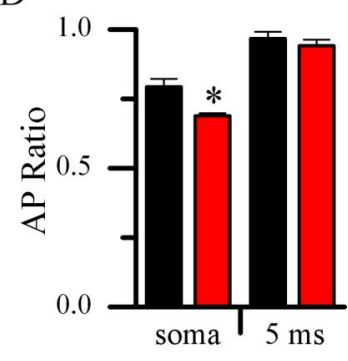

Figure 8. Brief depolarizations are more effective at stimulating $\mathrm{Mg}_{0}^{2+}$ unblock from NR1/2A than from NR1/2B receptors. $\boldsymbol{A}$, Superimposed currents from NR1/2A (black) and NR1/2B (red) receptors (bottom traces) during depolarizations of varying duration (1, 2, 5, 10, and $50 \mathrm{~ms}$; indicated by top traces) in the presence of $1 \mathrm{~mm}$ glutamate, $10 \mu \mathrm{m}$ glycine, and $1 \mathrm{~mm} \mathrm{Mg}_{0}^{2+}$. Currents are normalized to the $I_{\text {peak }}$ value after a $50 \mathrm{~ms}$ depolarization. The value of $I_{\text {peak }}$ after the $50 \mathrm{~ms}$ depolarization is indicated by a dotted line. Inset, Enlargement of the normalized inward peaks in response to the briefest depolarizations (1, 2, and $5 \mathrm{~ms})$. $\boldsymbol{B}$, Comparison of the $I_{\text {peak }}$ values after depolarizations of varying duration. Results are from NR1/2A ( $n=5 ;$ black) and from NR1/2B ( $n=4$; red) receptors. $I_{\text {peak }}$ values were normalized to the $I_{\text {peak }}$ after a 50 ms depolarization. Error bars indicate the means $\pm S E M$; ${ }^{* *} p<0.0005$. C, Superimposed currents (bottom traces) from NR1/2A (black) and NR1/2B (red) receptors during three APs (somatic, $5 \mathrm{~ms}$ extended, and $25 \mathrm{~ms}$ extended; top traces) in the presence of $1 \mathrm{~mm}$ glutamate, $10 \mu \mathrm{m}$ glycine, and $1 \mathrm{~mm} \mathrm{Mg}_{0}^{2+}$. Traces are normalized to the $I_{\text {peak,AP }}$ induced by the 25 ms extended AP. D, Pooled ratios of $I_{\text {peak,AP }}$ values in response to the somatic or 5 ms extended APs normalized to the $I_{\text {peak, AP }}$ value in response to the $25 \mathrm{~ms}$ extended AP. Results are from NR1/2A (black bars) and NR1/2B (red bars) receptors. Error bars indicate the means $\pm \mathrm{SEM} ;{ }^{*} p<0.01$.

nential equation. A triple exponential equation was not needed because a very slow component ( $\tau$ of several hundred milliseconds), which was observed when a prolonged application of $1 \mathrm{~mm}$ glutamate preceded the voltage jump, was absent. The time constant of the fast component $\left(\tau_{1}\right)$ of unblock did not differ significantly between $\mathrm{NR} 1 / 2 \mathrm{~A}$ and $\mathrm{NR} 1 / 2 \mathrm{~B}$ receptors, with values of $0.22 \pm 0.04$ and $0.24 \pm 0.06 \mathrm{~ms}$, respectively. In contrast, the time constant of the slow component $\left(\tau_{2}\right)$ of $\mathrm{Mg}_{\mathrm{o}}^{2+}$ unblock from NR1/2B receptors, $3.69 \pm 0.38 \mathrm{~ms}$, was significantly $(p<0.01)$ slower than from NR1/2A receptors, $2.13 \pm 0.27 \mathrm{~ms}$. In these experiments the amplitude of the slow component was similar for $\mathrm{NR} 1 / 2 \mathrm{~A}$ and NR1/2B receptors, with values of $32.2 \pm 8.3$ and $44.1 \pm 7.8 \%$, respectively. Thus our data suggest that the kinetics of $\mathrm{Mg}_{\mathrm{o}}^{2+}$ unblock depend slightly on the timing between receptor activation and membrane depolarization, with a very slow component $(\tau>100 \mathrm{~ms})$ occurring only after prolonged receptor activation. However, in all situations $\mathrm{Mg}_{\mathrm{o}}^{2+}$ unblock proceeds more rapidly from NR1/2A than from NR1/2B receptors.

\section{Effect of varying the duration of depolarization on}

$\mathrm{Mg}_{\mathrm{o}}^{2+}$ unblock

$\mathrm{Ca}^{2+}$ influx via NMDA receptors plays a critical role in many physiological processes. The kinetics of $\mathrm{Mg}_{\mathrm{o}}^{2+}$ unblock during membrane depolarization determine how many NMDA receptors become unblocked and hence are available to pass inward current after membrane repolarization. The repolarization- induced peak of inward current $\left(I_{\text {peak }}\right)$ is of particular interest because it is the point at which the largest NMDA receptormediated $\mathrm{Ca}^{2+}$ influx occurs (Garaschuk et al., 1996). During brief depolarizations slow $\mathrm{Mg}_{\mathrm{o}}^{2+}$ unblock should reduce the fraction of NMDA receptors from which $\mathrm{Mg}_{\mathrm{o}}^{2+}$ unblocks and thus the fraction of receptors available to pass inward current during repolarization. In addition, brief depolarizations should be less effective at stimulating $\mathrm{Mg}_{\mathrm{o}}^{2+}$ unblock from NR1/2B receptors (from which $\mathrm{Mg}_{\mathrm{o}}^{2+}$ unblock occurs more slowly) than from NR1/2A receptors. Thus the $I_{\text {peak }}$ after brief depolarizations should be reduced as compared with the $I_{\text {peak }}$ after long depolarizations, and the reduction should be greater for NR1/2B than for NR1/2A receptors. To test these hypotheses, we applied rapid voltage jumps from rest to $35 \mathrm{mV}$ of varying duration $(1,2,5,10,50 \mathrm{~ms})$ in the presence of $1 \mathrm{~mm}$ each glutamate and $\mathrm{Mg}_{\mathrm{o}}^{2+}$. Because there is not a strong effect of the timing between receptor activation and membrane depolarization on the kinetics of $\mathrm{Mg}_{\mathrm{o}}^{2+}$ unblock (see above), depolarizations were applied during prolonged agonist application (similar to Fig. 1). This allowed multiple voltage jumps to be applied during a single agonist application. Depolarizations were separated by $100 \mathrm{~ms}$ intervals, which is $>10$-fold longer than the $\tau$ of the slow component of $\mathrm{Mg}_{\mathrm{o}}^{2+}$ reblock, allowing steady-state block to be reached between each depolarization.

As expected, longer duration depolarizations resulted in a larger $I_{\text {peak }}$ (Fig. $8 \mathrm{~A}$ ). To quantify the relationship between depolarization duration and $I_{\text {peak }}$, we normalized all $I_{\text {peak }}$ values to the $I_{\text {peak }}$ after a $50 \mathrm{~ms}$ depolarization. In experiments from both NR1/2A and NR1/2B receptors the $1 \mathrm{~ms}$ depolarizations induced an $I_{\text {peak }}$ that was $<70 \%$ of the $I_{\text {peak }}$ after a $50 \mathrm{~ms}$ depolarization (Fig. $8 \mathrm{~B}$ ). Only after the depolarization duration was increased to $10 \mathrm{~ms}$ was the $I_{\text {peak }}$ not significantly smaller than the $I_{\text {peak }}$ after a $50 \mathrm{~ms}$ depolarization. In addition, after depolarizations of $<10 \mathrm{~ms}$, the normalized $I_{\text {peak }}$ from NR1/2A receptors was significantly larger than the normalized $I_{\text {peak }}$ from NR1/2B receptors (Fig. 8 B). Thus slow $\mathrm{Mg}_{\text {o }}^{2+}$ unblock blunts inward currents via NR1/2A and NR1/2B receptors after brief depolarizations. However, brief depolarizations $(<10 \mathrm{~ms})$ are able to stimulate more $\mathrm{Mg}_{\mathrm{o}}^{2+}$ unblock from NR1/2A than from NR1/2B receptors.

Although square voltage jumps are easily applied experimentally, physiological voltage changes occur with slower rising and falling phases. Recently, there has been a strong interest in backpropagating APs (b-APs) invading the dendritic tree and providing the depolarization needed for $\mathrm{Mg}_{\mathrm{o}}^{2+}$ unblock of NMDA receptors during synaptic activity (Magee and Johnston, 1997; Markram et al., 1997; Bi and Poo, 1998). Within dendrites near the soma the b-APs are rapid, often having a half-width of $<2 \mathrm{~ms}$. Farther out in the dendritic tree the b-AP half-width can be $>10$ ms (Bernard and Johnston, 2003). In all instances the rising and 
falling phases of b-AP waveforms are slower than the square pulses we have used above.

To test whether the NR2 subunit-dependent differences in $\mathrm{Mg}_{\mathrm{o}}^{2+}$ unblocking kinetics also impact NMDA receptor activity during physiological depolarizations, we voltage-clamped transfected HEK 293T cells to AP waveforms. Three waveforms were used: an unmodified AP recorded from the soma of a hippocampal CA1 pyramidal cell (termed somatic AP) and two APs that we modified so the duration at the most depolarized voltage was 5 ms ( $5 \mathrm{~ms}$ extended AP) or $25 \mathrm{~ms}$ ( $25 \mathrm{~ms}$ extended AP). The ability of each waveform to generate inward current via NMDA receptors after $\mathrm{Mg}_{\mathrm{o}}^{2+}$ unblock was quantified by measuring the peak inward current during the repolarizing phase of the APs $\left(I_{\text {peak,AP }}\right)$. The $25 \mathrm{~ms}$ extended AP should give maximum $\mathrm{Mg}_{\mathrm{o}}^{2+}$ unblock from both NR1/2A and NR1/2B receptors. Thus $I_{\text {peak,AP }}$ induced by the somatic AP and by the $5 \mathrm{~ms}$ extended AP was normalized to $I_{\text {peak,AP }}$ induced by the $25 \mathrm{~ms}$ extended AP. The normalized values of $I_{\text {peak,AP }}$ for the $5 \mathrm{~ms}$ AP were close to 1 for both NR1/2A and NR1/2B receptors (Fig. $8 C, D$ ). This suggests that the 5 and 25 ms extended APs induced a similar amount of $\mathrm{Mg}^{2+}$ unblock. In contrast, the normalized values of $I_{\text {peak,AP }}$ for the somatic AP were significantly $(p<0.001)<1$ for both NR1/2A and NR1/2B receptors (Fig. $8 C, D$ ). Thus the somatic AP was too brief to stimulate full $\mathrm{Mg}_{\mathrm{o}}^{2+}$ unblock from either NR1/2A or NR1/2B receptors. The normalized value of $I_{\text {peak,AP }}$ for the somatic AP was also significantly smaller for NR1/2A than for NR1/2B receptors (Fig. $8 D$ ). This suggests that somatic APs are more effective at stimulating $\mathrm{Mg}_{\mathrm{o}}^{2+}$ unblock from NR1/2A than from NR1/2B receptors. Thus during synaptic activity postsynaptic APs coincident with presynaptic glutamate release are more effective at stimulating $\mathrm{Mg}_{\mathrm{o}}^{2+}$ unblock from NR1/2A than from NR1/2B receptors.

\section{Discussion}

Many pharmacological and biophysical properties of NMDA receptors are, at least in part, determined by the identity of the NR2 subunit (Dingledine et al., 1999). Our results show that $\mathrm{Mg}_{\mathrm{o}}^{2+}$ unblocking kinetics are also NR2 subunit-dependent. $\mathrm{Mg}_{\mathrm{o}}^{2+}$ unblocks from NR1/2A and NR1/2B receptors with a prominent slow component that is not present when $\mathrm{Mg}_{\mathrm{o}}^{2+}$ unblocks from NR1/2C or NR1/2D receptors (Fig. 2). In addition, the slow component of $\mathrm{Mg}_{\mathrm{o}}^{2+}$ unblock from NR1/2A and NR1/2B receptors is not equivalent; $\mathrm{Mg}_{\mathrm{o}}^{2+}$ unblocks from NR1/2B receptors more slowly than from NR1/2A receptors (Fig. 4). These NR2 subunit differences in $\mathrm{Mg}_{\mathrm{o}}^{2+}$ unblock render brief depolarizations, including APs, more effective at stimulating $\mathrm{Mg}_{\mathrm{o}}^{2+}$ unblock from NR1/2A than from NR1/2B receptors (Fig. 8).

\section{Comparison with previous studies}

Our data are consistent with previous studies describing slow $\mathrm{Mg}^{2+}$ unblock from native hippocampal and cortical NMDA receptors (Spruston et al., 1995; Vargas-Caballero and Robinson, 2003; Kampa et al., 2004) in that the hippocampus and cortex predominantly express the NR2A and NR2B subunits (Monyer et al., 1994). Our data also provide potential explanations for discrepancies between previous studies of the kinetics of $\mathrm{Mg}_{\mathrm{o}}^{2+}$ unblock. When depolarizations occurred during prolonged receptor activation, Vargas-Caballero and Robinson (2003) reported that slow $\mathrm{Mg}_{\mathrm{o}}^{2+}$ unblock had a single component $\left(\tau_{\mathrm{s} 1}>10 \mathrm{~ms}\right)$, whereas Kampa and colleagues (2004) reported that slow $\mathrm{Mg}_{\mathrm{o}}^{2+}$ unblock contained two components $\left(\tau_{\mathrm{s} 1} \sim 4\right.$ and $\left.\tau_{\mathrm{s} 2} \sim 300 \mathrm{~ms}\right)$. One experimental difference between these two studies is the concentration of agonists used to activate NMDA receptors.
Vargas-Caballero and Robinson (2003) used $25 \mu \mathrm{M}$ NMDA, whereas Kampa and colleagues (2004) used 1 mm glutamate. We find that at high agonist concentrations the main component of slow $\mathrm{Mg}_{\mathrm{o}}^{2+}$ unblock is accelerated (from $\tau_{2}$ between 5 and $9 \mathrm{~ms}$ to $\mathrm{at}_{2}$ between 2 and $5 \mathrm{~ms}$ ), and an additional very slow component ( $\tau=200-400 \mathrm{~ms}$ ) is discernible (Fig. 6). It is also likely that the $\tau_{\text {s1 }}$ reported by Vargas-Caballero and Robinson (2003) was slower than the $\tau_{\mathrm{s} 1}$ reported by Kampa and colleagues (2004), because Vargas-Caballero and Robinson (2003) used younger animals than Kampa and colleagues (2004), which should express a higher percentage of NR1/2B receptors.

The additional very slow component of $\mathrm{Mg}_{\mathrm{o}}^{2+}$ unblock is not present when depolarizations occur shortly after agonist application (Fig. 7). This is in agreement with Kampa and colleagues (2004) and shows that the kinetics of $\mathrm{Mg}_{\mathrm{o}}^{2+}$ unblock depend on the relative timing of receptor activation and membrane depolarization. However, after a prolonged glutamate application, we find that the very slow component of $\mathrm{Mg}_{\mathrm{o}}^{2+}$ unblock accounts for $<10 \%$ of the total current rather than $\sim 30 \%$ of the total current reported previously (Kampa et al., 2004). The source of this discrepancy is not clear. Resolution of this conflict is important because changes in the kinetics of $\mathrm{Mg}_{\mathrm{o}}^{2+}$ unblock with prolonged receptor activation influence the time window for STDP induction (Kampa et al., 2004).

Several previously published models of NMDA receptor function (Jahr and Stevens, 1990; Antonov and Johnson, 1999; Sobolevsky and Yelshansky, 2000) do not predict a slow component of $\mathrm{Mg}_{\mathrm{o}}^{2+}$ unblock in response to a depolarizing voltage jump (data not shown). In order to explain the surprising observation of slow $\mathrm{Mg}_{\mathrm{o}}^{2+}$ unblock, two models have been proposed (Kampa et al., 2004; Vargas-Caballero and Robinson, 2004). These models suggest that occupation of the channel by $\mathrm{Mg}_{\mathrm{o}}^{2+}$ moderately accelerates only the rate of channel closure (Vargas-Caballero and Robinson, 2004) or accelerates rates of channel closure and agonist unbinding, along with increasing the occupancy of desensitized states (Kampa et al., 2004). These models predict accurately the appearance of slow component or components of $\mathrm{Mg}_{\mathrm{o}}^{2+}$ unlock. They also are supported by the observed reduction in singlechannel burst duration of cortical NMDA receptors in the presence of $\mathrm{Mg}_{\mathrm{o}}^{2+}$ (Ascher and Nowak, 1988), as would be predicted if $\mathrm{Mg}^{2+}$ accelerates channel closure. These models, however, are not fully consistent with other observations. If $\mathrm{Mg}_{\mathrm{o}}^{2+}$ accelerates channel closure, the $\mathrm{IC}_{50}$ for $\mathrm{Mg}_{\mathrm{o}}^{2+}$ inhibition of whole-cell currents should be lower than the $\mathrm{Mg}_{\mathrm{o}}^{2+} K_{\mathrm{D}}$ calculated from singlechannel measurements, a prediction that disagrees with previous measurements (Qian et al., 2002). Additional relevant data involve the organic NMDA receptor channel blocker amantadine, which unblocks from open channels even faster than $\mathrm{Mg}_{\mathrm{o}}^{2+}$. Burst analysis demonstrates that amantadine does accelerate channel closure moderately (Blanpied et al., 2005). After a depolarizing voltage step, amantadine, like $\mathrm{Mg}_{\mathrm{o}}^{2+}$, exhibits a slow component of channel unblock. However, the slow component of unblock is much slower for amantadine than for $\mathrm{Mg}^{2+}$ (Blanpied et al., 2005). These data suggest that a complete understanding of the mechanistic basis of the slow component of $\mathrm{Mg}_{\mathrm{o}}^{2+}$ unblock awaits additional research.

We also have described here a slow component of $\mathrm{Mg}_{\mathrm{o}}^{2+}$ reblock of NR1/2A and NR1/2B receptors (Fig. 5). This contrasts with previous studies (Spruston et al., 1995; Vargas-Caballero and Robinson, 2003; Kampa et al., 2004) that report nearinstantaneous $\mathrm{Mg}_{\mathrm{o}}^{2+}$ reblock of native NMDA receptors. Because the slow phase of $\mathrm{Mgo}_{\mathrm{o}}^{2+}$ reblock observed here is small, it is possible that it was not observed in previous studies that used nucleated patches (Spruston et al., 1995; Vargas-Caballero and Robinson, 
2003; Kampa et al., 2004), which typically yield relatively small currents. We were able to quantify slow $\mathrm{Mg}^{2+}$ reblock only from wholecell records that had large currents $(>100 \mathrm{pA})$ at $-65 \mathrm{mV}$ in the presence of $1 \mathrm{mM} \mathrm{Mg}^{2+}$. Although of small amplitude, the slow phase of $\mathrm{Mg}_{\mathrm{o}}^{2+}$ reblock provides a relatively long window during which highly significant $\mathrm{Ca}^{2+}$ influx could occur after a postsynaptic AP that coincides with synaptic input.

We have studied NMDA receptors containing one of the four NR2 subunits. However, there is evidence that triheteromeric receptors, which contain more than one type of NR2 subunit, exist within many brain regions, including the cortex (Sheng et al., 1994; Didier et al., 1995; Chazot and Stephenson, 1997; Luo et al., 1997), cerebellum (Chazot et al., 1994; Cathala et al., 2000; Brickley et al., 2003), and substantia nigra (Jones and Gibb, 2005). Coexpression of the NR1, NR2A, and NR2D subunits in Xenopus oocytes yields a receptor with many characteristics intermediate between NR1/2A and NR1/2D receptors (Cheffings and Colquhoun, 2000). It is tempting to speculate that triheteromeric receptors would show intermediate $\mathrm{Mg}_{\mathrm{o}}^{2+}$ unblocking kinetics. However, testing this hypothesis would be challenging because it is difficult to isolate triheteromeric receptors within heterologous systems (Vicini et al., 1998).

\section{Implications for synaptic plasticity}

$\mathrm{Ca}^{2+}$ influx via NMDA receptors during coincident synaptic activity and postsynaptic depolarization underlies long-term changes in synaptic strength at many synapses (Bliss and Collingridge, 1993). However, not all NMDA receptors are equivalent. Because NR1/2C and NR1/2D receptors have a lower affinity for $\mathrm{Mg}_{\mathrm{o}}^{2+}$ (Monyer et al., 1994; Kuner and Schoepfer, 1996; Qian et al., 2005), they allow significant $\mathrm{Ca}^{2+}$ influx near typical resting membrane potentials where NR1/2A and NR1/2B receptors are $>95 \%$ blocked. In addition, we show here that the relatively weak $\mathrm{Mg}_{\mathrm{o}}^{2+}$ block of NR1/2C and NR1/2D receptor currents is relieved more rapidly after depolarization than is the $\mathrm{Mg}_{\mathrm{o}}^{2+}$ block of NR1/2A and NR1/2B receptor currents (Fig. 2). Thus $\mathrm{Mg}_{\mathrm{o}}^{2+}$ block has a stronger influence on NR1/2A and NR1/2B receptor currents than $\mathrm{NR} 1 / 2 \mathrm{C}$ and $\mathrm{NR} 1 / 2 \mathrm{D}$ receptor currents, rendering $\mathrm{NR} 1 / 2 \mathrm{~A}$ and NR1/2B receptors more effective coincidence detectors.

Several recent studies have suggested that selective NR1/2A receptor activation leads preferentially to long-term potentiation (LTP), whereas selective NR1/2B receptor activation leads to long-term depression (LTD) (Liu et al., 2004; Massey et al., 2004; Kim et al., 2005; Mallon et al., 2005). Based on proposed differences in the $\mathrm{Ca}^{2+}$ threshold for LTP and LTD induction (Bienenstock et al., 1982; Cormier et al., 2001), our data suggest a mechanism that could help to differentiate the physiological impact of $\mathrm{NR} 1 / 2 \mathrm{~A}$ and $\mathrm{NR} 1 / 2 \mathrm{~B}$ receptor activation. In response to brief membrane depolarizations, the relatively faster unblock of $\mathrm{Mg}_{\mathrm{o}}^{2+}$ from NR1/2A receptors would result in greater $\mathrm{Ca}^{2+}$ influx (Fig. 8), favoring LTP, whereas the relatively slower unblock of $\mathrm{Mg}_{\mathrm{o}}^{2+}$ from NR1/2B receptors would result in lower $\mathrm{Ca}^{2+}$ influx, favoring LTD. It should be noted, however, that it is unlikely that there is an exclusive association of NR1/2A receptors with LTP and of NR1/2B receptors with LTD (Tang et al., 1999; Berberich et al., 2005; Toyoda et al., 2005; Weitlauf et al., 2005; Neyton and Paoletti, 2006).

In many studies of the NR2 subunit dependence of synaptic plasticity, induction protocols that involve the pairing of presynaptic stimulation with prolonged postsynaptic depolarization are used. Such induction protocols reduce the relevance of the kinetics of $\mathrm{Mg}_{\mathrm{o}}^{2+}$ unblock. We also expect slow $\mathrm{Mg}_{\mathrm{o}}^{2+}$ unblock to have limited impact during relatively small synaptic depolarizations: slow unblock time constants are faster, amplitudes are smaller, and NR2 subunit-dependent differences are smaller at more hyperpolarized potentials (Fig. 4). The kinetics of $\mathrm{Mg}_{\mathrm{o}}^{2+}$ unblock are most clearly of critical importance when plasticity is induced with STDP protocols, which pair synaptic input with postsynaptic APs (Magee and Johnston, 1997; Markram et al., 1997; Bi and Poo, 1998). The NR2 subunit differences in $\mathrm{Mg}_{\mathrm{o}}^{2+}$ unblock kinetics reported here should help to determine the magnitude of $\mathrm{Ca}^{2+}$ influx mediated by NR1/2A and NR1/2B receptors in response to brief, large-amplitude depolarizations such as APs.

\section{References}

Antonov SM, Johnson JW (1999) Permeant ion regulation of N-methyl-Daspartate receptor channel block by $\mathrm{Mg}^{2+}$. Proc Natl Acad Sci USA 96:14571-14576.

Ascher P, Nowak L (1988) The role of divalent cations in the N-methyl-Daspartate responses of mouse central neurones in culture. J Physiol (Lond) 399:247-266.

Bear MF, Kleinschmidt A, Gu QA, Singer W (1990) Disruption of experience-dependent synaptic modifications in striate cortex by infusion of an NMDA receptor antagonist. J Neurosci 10:909-925.

Benveniste M, Mayer ML (1995) Trapping of glutamate and glycine during open channel block of rat hippocampal neuron NMDA receptors by 9-aminoacridine. J Physiol (Lond) 483[Pt 2]:367-384.

Berberich S, Punnakkal P, Jensen V, Pawlak V, Seeburg PH, Hvalby O, Kohr G (2005) Lack of NMDA receptor subtype selectivity for hippocampal long-term potentiation. J Neurosci 25:6907-6910.

Bernard C, Johnston D (2003) Distance-dependent modifiable threshold for action potential back-propagation in hippocampal dendrites. J Neurophysiol 90:1807-1816.

Bi GQ, Poo MM (1998) Synaptic modifications in cultured hippocampal neurons: dependence on spike timing, synaptic strength, and postsynaptic cell type. J Neurosci 18:10464-10472.

Bienenstock EL, Cooper LN, Munro PW (1982) Theory for the development of neuron selectivity: orientation specificity and binocular interaction in visual cortex. J Neurosci 2:32-48.

Blanpied TA, Clarke RJ, Johnson JW (2005) Amantadine inhibits NMDA receptors by accelerating channel closure during channel block. J Neurosci 25:3312-3322.

Bliss TV, Collingridge GL (1993) A synaptic model of memory: long-term potentiation in the hippocampus. Nature 361:31-39.

Brickley SG, Misra C, Mok MH, Mishina M, Cull-Candy SG (2003) NR2B and NR2D subunits coassemble in cerebellar Golgi cells to form a distinct NMDA receptor subtype restricted to extrasynaptic sites. J Neurosci 23:4958-4966.

Cathala L, Misra C, Cull-Candy S (2000) Developmental profile of the changing properties of NMDA receptors at cerebellar mossy fiber $\rightarrow$ granule cell synapses. J Neurosci 20:5899-5905.

Chapman AG (2000) Glutamate and epilepsy. J Nutr 130:1043S-1045S.

Chazot PL, Stephenson FA (1997) Molecular dissection of native mammalian forebrain NMDA receptors containing the NR1 C2 exon: direct demonstration of NMDA receptors comprising NR1, NR2A, and NR2B subunits within the same complex. J Neurochem 69:2138-2144.

Chazot PL, Coleman SK, Cik M, Stephenson FA (1994) Molecular characterization of $N$-methyl-D-aspartate receptors expressed in mammalian cells yields evidence for the coexistence of three subunit types within a discrete receptor molecule. J Biol Chem 269:24403-24409.

Cheffings CM, Colquhoun D (2000) Single channel analysis of a novel NMDA channel from Xenopus oocytes expressing recombinant NRla, NR2A, and NR2D subunits. J Physiol (Lond) 526[Pt 3]:481-491.

Chen N, Luo T, Raymond LA (1999) Subtype dependence of NMDA receptor channel open probability. J Neurosci 19:6844-6854.

Cline HT, Debski EA, Constantine-Paton M (1990) The role of the NMDA receptor in the development of the frog visual system. Adv Exp Med Biol 268:197-203.

Cormier RJ, Greenwood AC, Connor JA (2001) Bidirectional synaptic plasticity correlated with the magnitude of dendritic calcium transients above a threshold. J Neurophysiol 85:399-406.

Cull-Candy S, Brickley S, Farrant M (2001) NMDA receptor subunits: diversity, development, and disease. Curr Opin Neurobiol 11:327-335. 
Didier M, Xu M, Berman SA, Bursztajn S (1995) Differential expression and co-assembly of NMDA $\zeta 1$ and $\varepsilon$ subunits in the mouse cerebellum during postnatal development. NeuroReport 6:2255-2259.

Dingledine R, Borges K, Bowie D, Traynelis SF (1999) The glutamate receptor ion channels [review]. Pharmacol Rev 51:7-61.

Erisir A, Harris JL (2003) Decline of the critical period of visual plasticity is concurrent with the reduction of NR2B subunit of the synaptic NMDA receptor in layer 4. J Neurosci 23:5208-5218.

Erreger K, Dravid SM, Banke TG, Wyllie DJ, Traynelis SF (2005) Subunitspecific gating controls rat NR1/NR2A and NR1/NR2B NMDA channel kinetics and synaptic signaling profiles. J Physiol (Lond) 563:345-358.

Garaschuk O, Schneggenburger R, Schirra C, Tempia F, Konnerth A (1996) Fractional $\mathrm{Ca}^{2+}$ currents through somatic and dendritic glutamate receptor channels of rat hippocampal CA1 pyramidal neurones. J Physiol (Lond) 491[Pt 3]:757-772.

Giffard RG, Monyer H, Christine CW, Choi DW (1990) Acidosis reduces NMDA receptor activation, glutamate neurotoxicity, and oxygen-glucose deprivation neuronal injury in cortical cultures. Brain Res 506:339-342.

Heynen AJ, Quinlan EM, Bae DC, Bear MF (2000) Bidirectional, activitydependent regulation of glutamate receptors in the adult hippocampus in vivo. Neuron 28:527-536.

Iwasato T, Datwani A, Wolf AM, Nishiyama H, Taguchi Y, Tonegawa S, Knopfel T, Erzurumlu RS, Itohara S (2000) Cortex-restricted disruption of NMDAR1 impairs neuronal patterns in the barrel cortex. Nature 406:726-731.

Jahr CE, Stevens CF (1990) Voltage dependence of NMDA-activated macroscopic conductances predicted by single-channel kinetics. J Neurosci 10:3178-3182.

Jones S, Gibb AJ (2005) Functional NR2B- and NR2D-containing NMDA receptor channels in rat substantia nigra dopaminergic neurones. J Physiol (Lond) 569:209-221.

Kampa BM, Clements J, Jonas P, Stuart GJ (2004) Kinetics of $\mathrm{Mg}^{2+}$ unblock of NMDA receptors: implications for spike-timing dependent synaptic plasticity. J Physiol (Lond) 556:337-345.

Kim MJ, Dunah AW, Wang YT, Sheng M (2005) Differential roles of NR2Aand NR2B-containing NMDA receptors in Ras-ERK signaling and AMPA receptor trafficking. Neuron 46:745-760.

Kuner T, Schoepfer R (1996) Multiple structural elements determine subunit specificity of $\mathrm{Mg}^{2+}$ block in NMDA receptor channels. J Neurosci 16:3549-3558.

Laurie DJ, Putzke J, Zieglgansberger W, Seeburg PH, Tolle TR (1995) The distribution of splice variants of the NMDAR1 subunit mRNA in adult rat brain. Brain Res Mol Brain Res 32:94-108.

Lisman JE, McIntyre CC (2001) Synaptic plasticity: a molecular memory switch. Curr Biol 11:R788-R791.

Liu L, Wong TP, Pozza MF, Lingenhoehl K, Wang Y, Sheng M, Auberson YP, Wang YT (2004) Role of NMDA receptor subtypes in governing the direction of hippocampal synaptic plasticity. Science 304:1021-1024.

Luo J, Wang Y, Yasuda RP, Dunah AW, Wolfe BB (1997) The majority of $\mathrm{N}$-methyl-D-aspartate receptor complexes in adult rat cerebral cortex contain at least three different subunits (NR1/NR2A/NR2B). Mol Pharmacol 51:79-86.

Magee JC, Johnston D (1997) A synaptically controlled, associative signal for Hebbian plasticity in hippocampal neurons. Science 275:209-213.

Mallon AP, Auberson YP, Stone TW (2005) Selective subunit antagonists suggest an inhibitory relationship between NR2B and NR2A subunit containing $\mathrm{N}$-methyl-D-aspartate receptors in hippocampal slices. Exp Brain Res 162:374-383.

Markram H, Lubke J, Frotscher M, Roth A, Sakmann B (1997) Physiology and anatomy of synaptic connections between thick tufted pyramidal neurones in the developing rat neocortex. J Physiol (Lond) $500[\mathrm{Pt}$ 2]:409-440.

Massey PV, Johnson BE, Moult PR, Auberson YP, Brown MW, Molnar E, Collingridge GL, Bashir ZI (2004) Differential roles of NR2A- and NR2B-containing NMDA receptors in cortical long-term potentiation and long-term depression. J Neurosci 24:7821-7828.

Mayer ML, Westbrook GL, Guthrie PB (1984) Voltage-dependent block by $\mathrm{Mg}^{2+}$ of NMDA responses in spinal cord neurones. Nature 309:261-263.
Meldrum BS (1992) Excitatory amino acid receptors and disease. Curr Opin Neurol Neurosurg 5:508-513.

Moghaddam B (2003) Bringing order to the glutamate chaos in schizophrenia. Neuron 40:881-884.

Monyer H, Burnashev N, Laurie DJ, Sakmann B, Seeburg PH (1994) Developmental and regional expression in the rat brain and functional properties of four NMDA receptors. Neuron 12:529-540.

Neyton J, Paoletti P (2006) Relating NMDA receptor function to receptor subunit composition: limitations of the pharmacological approach. J Neurosci 26:1331-1333.

Nowak L, Bregestovski P, Ascher P, Herbet A, Prochiantz A (1984) Magnesium gates glutamate-activated channels in mouse central neurones. $\mathrm{Na}$ ture 307:462-465.

Paoletti P, Neyton J, Ascher P (1995) Glycine-independent and subunitspecific potentiation of NMDA responses by extracellular $\mathrm{Mg}^{2+}$. Neuron 15:1109-1120.

Qian A, Antonov SM, Johnson JW (2002) Modulation by permeant ions of $\mathrm{Mg}^{2+}$ inhibition of NMDA-activated whole-cell currents in rat cortical neurons. J Physiol (Lond) 538:65-77.

Qian A, Buller AL, Johnson JW (2005) NR2 subunit dependence of NMDA receptor channel block by external $\mathrm{Mg}^{2+}$. J Physiol (Lond) 562:319-331.

Ramoa AS, Mower AF, Liao D, Jafri SI (2001) Suppression of cortical NMDA receptor function prevents development of orientation selectivity in the primary visual cortex. J Neurosci 21:4299-4309.

Sheng M, Cummings J, Roldan LA, Jan YN, Jan LY (1994) Changing subunit composition of heteromeric NMDA receptors during development of rat cortex. Nature 368:144-147.

Sobolevsky AI, Yelshansky MV (2000) The trapping block of NMDA receptor channels in acutely isolated rat hippocampal neurones. J Physiol (Lond) 526[Pt 3]:493-506.

Spruston N, Jonas P, Sakmann B (1995) Dendritic glutamate receptor channels in rat hippocampal CA3 and CA1 pyramidal neurons. J Physiol (Lond) 482[Pt 2]:325-352.

Tang CM, Dichter M, Morad M (1990) Modulation of the N-methyl-Daspartate channel by extracellular $\mathrm{H}^{+}$. Proc Natl Acad Sci USA 87:6445-6449.

Tang YP, Shimizu E, Dube GR, Rampon C, Kerchner GA, Zhuo M, Liu G, Tsien JZ (1999) Genetic enhancement of learning and memory in mice. Nature 401:63-69.

Tovar KR, Westbrook GL (1999) The incorporation of NMDA receptors with a distinct subunit composition at nascent hippocampal synapses in vitro. J Neurosci 19:4180-4188.

Toyoda H, Zhao MG, Zhuo M (2005) Roles of NMDA receptor NR2A and NR2B subtypes for long-term depression in the anterior cingulate cortex. Eur J Neurosci 22:485-494.

Traynelis SF, Cull-Candy SG (1990) Proton inhibition of N-methyl-Daspartate receptors in cerebellar neurons. Nature 345:347-350.

Tsai G, Coyle JT (2002) Glutamatergic mechanisms in schizophrenia. Annu Rev Pharmacol Toxicol 42:165-179.

Vargas-Caballero M, Robinson HP (2003) A slow fraction of $\mathrm{Mg}^{2+}$ unblock of NMDA receptors limits their contribution to spike generation in cortical pyramidal neurons. J Neurophysiol 89:2778-2783.

Vargas-Caballero M, Robinson HP (2004) Fast and slow voltage-dependent dynamics of magnesium block in the NMDA receptor: the asymmetric trapping block model. J Neurosci 24:6171-6180.

Vicini S, Wang JF, Li JH, Zhu WJ, Wang YH, Luo JH, Wolfe BB, Grayson DR (1998) Functional and pharmacological differences between recombinant $N$-methyl-D-aspartate receptors. J Neurophysiol 79:555-566.

Weitlauf C, Honse Y, Auberson YP, Mishina M, Lovinger DM, Winder DG (2005) Activation of NR2A-containing NMDA receptors is not obligatory for NMDA receptor-dependent long-term potentiation. J Neurosci 25:8386-8390.

Wenzel A, Villa M, Mohler H, Benke D (1996) Developmental and regional expression of NMDA receptor subtypes containing the NR2D subunit in rat brain. J Neurochem 66:1240-1248.

Zeron MM, Hansson O, Chen N, Wellington CL, Leavitt BR, Brundin P, Hayden MR, Raymond LA (2002) Increased sensitivity to $N$-methyl-Daspartate receptor-mediated excitotoxicity in a mouse model of Huntington's disease. Neuron 33:849-860. 